\title{
Palaeomagnetic Studies on a Quaternary Volcanic Region in Japan*
}

\author{
By \\ T. NAGATA, S. AKIMOTO, S. UYEDA, Y. SHIMIZU, M. OZIMA, \\ K. KOBAYASHI \\ Geophysical Institute, Tokyo University \\ and \\ H. KUNO \\ Geological Institute, Tokyo University
}

(Read Oct. 17, 1956; Received Jun. 17, 1957)

\begin{abstract}
Palaeomagnetic studies have been conducted of the voltanic rocks in the North-Izu and Hakone volcanic region, Japan, where complete succession of lavas has been determined by one of us (H.K.). By sampling $4 \sim 7$ oriented rock specimens at each of 57 sites, the period from the very beginning of the Pleistocene to Holocene has been covered. The maximum time interval between two consecutive samples may probably be not more than several tens of thousand years except that between two samples of middle to younger Pleistocene when the volcanic activity did not occur within the region concerned. Care was taken not to use the rock samples of which natural remanent magnetization may have suffered from any significant disturbances, geolgically, chemically, magnetically or otherwise. Selection of proper samples was performed according to the criteria for the stability of remanent magnetization proposed by us previously (Journ. Geomag. Geoelec., 6, No. 4, 1955). The major findings obtained through the present study are: 1) During the whole Quaternary age, the geomagnetic centred dipole has been fluctuating around an axis of which north pole wandered from $72^{\circ} \mathrm{N}, 86^{\circ} \mathrm{E}$ to $81^{\circ} \mathrm{N}, 32^{\circ} \mathrm{W}$. 2) The direction of polarization of the centred dipole was reversed at a time in the earliest Quaternary, namely during the middle period of the formation of the Usami volcano.
\end{abstract}

\section{Introduction}

Recent investigations on palaeomagnetism have brought about many findings of great geophysical importance, especially with regards to the long controversial hypotheses of the polar wandering, the continental drift and the reversals of the geomagnetic field in the past geological time. Excellent summaries on these works are found in the publications of S.K. Runcorn [1], P.M.S. Blackett [2] and E. Irving [3]. Many authors, on the basis of their own measurements and others', have suggested that the earth's magnetic field had undergone repeated total reversals during the geological time. Such suggestions, though plausible, would be completely justified as

* Contribution from Division of Geomagnetism and Geoelectricity, Geophysical Institute, Tokyo University. Series II, No. 64 . 
physical truth only when the contemporeinity of reversely magnetized rocks from various localities of the world could be proved with sufficient certainty for each suggested reversals. Such absolute datings of rocks are, however, almost inaccessible at the present time. In general, the ages of rocks are determined by geological means more precisely for the younger strata. Therefore, since 1954 we have engaged ourselves with a palaeomagnetic research on a Quaternary volcanic rocks of North-Izu and Hakone volcanic region (Fig. 1), where the complete succession of lavas had been deter-

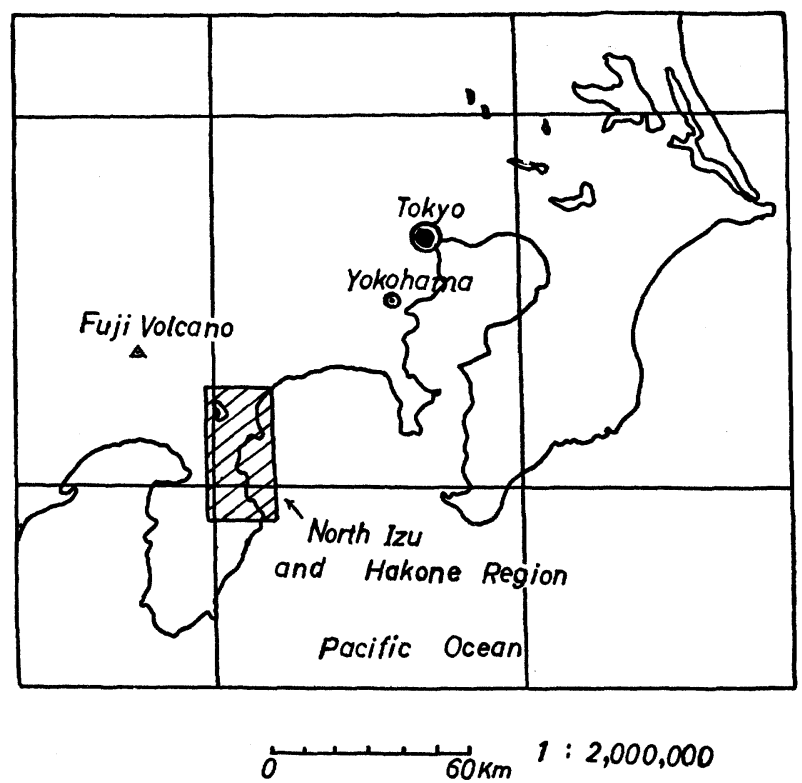

Fig. 1 Map showing the locality of the North-Izu and Hakone volcanic region.

mined by one of us (H.K.) [4], with the hope that our data would possibly be compared with the data for other parts of the world such as Iceland and France, where reversely magnetized rocks of early Quaternary were reported by J. Hospers [5], T. Einarsson and Th. Sigurgeirsson [6] and A. Roche [7]. It must here be noted that Y. Kato in 1941 conducted a palaeomagnetic research on the North-Izu and Hakone region and found that some rocks of early Quaternary and Tertiary are reversely magnetized [8].

\section{Outline of the Geologic History}

The region in question lies about $90 \mathrm{~km}$ southwest of the city of Tokyo (Fig.1). The following is a summary of the geologic history of the region already described elsewhere by H. Kuno [4]. The succession of the geologic units is shown in Table 1 and their distribution in Fig. 2.

The basement of the region is composed of older Miocene volcanic rocks named the Yugasima Group attaining to several thousand metres in thickness. Volcanic rocks ranging in age from midle Miocene to Pliocene were accumulated on this basement. In Plio-Pleistocene or older Pleistocene the central part of the present Izu peninsula 
Table 1. Stratigraphic succession of rocks of North-Izu and Hakone region and the estimated period of their eruption.

\begin{tabular}{|c|c|c|c|c|c|}
\hline \multicolumn{2}{|c|}{ Geologic age } & $10^{3}$ years & \multicolumn{3}{|c|}{ Geologic units and their thicknesses } \\
\hline \multirow{12}{*}{ 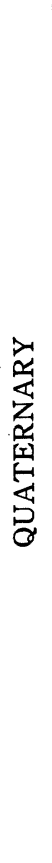 } & Holocene & \multirow{3}{*}{$\begin{array}{r}10 \\
100\end{array}$} & & & OMMURO-YAMA \\
\hline & \multirow{11}{*}{ 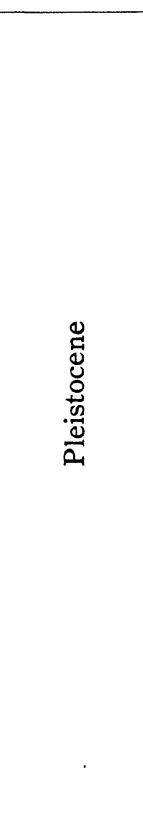 } & & \multirow{5}{*}{ 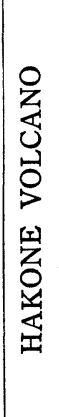 } & $\begin{array}{l}\text { Central Cone lavas } \\
\text { CC } 700 \mathrm{~m}\end{array}$ & VOLCANO GROUP \\
\hline & & & & \multicolumn{2}{|c|}{ Erosion interval } \\
\hline & & \multirow{3}{*}{$\begin{array}{l}200 \\
300 \\
400 \\
500\end{array}$} & & $\begin{array}{l}\text { Young Somma } \\
\text { lavas }\end{array}$ & $300 \mathrm{~m}$ \\
\hline & & & & \multicolumn{2}{|c|}{ Erosion interval } \\
\hline & & & & $\begin{array}{l}\text { Old Somma OS } \\
\text { lavas }\end{array}$ & $700 \mathrm{~m}$ \\
\hline & & \multirow{2}{*}{600} & \multicolumn{3}{|c|}{ Erosion interval } \\
\hline & & & & $\begin{array}{l}\text { YUGAWARA } \\
\text { VOLCANO }\end{array}$ & V $300 \mathrm{~m}$ \\
\hline & & 700 & & \multicolumn{2}{|c|}{ Erosion interval } \\
\hline & & \multirow[t]{3}{*}{800} & & $\begin{array}{l}\text { TAGA } \\
\text { VOLCANO }\end{array}$ & $V 500 \mathrm{~m}$ \\
\hline & & & & Erosion ir & erval \\
\hline & & & & $\begin{array}{l}\text { USAMI } \\
\text { VOLCANO }\end{array}$ & V $300 \mathrm{~m}$ \\
\hline \multirow{3}{*}{ 营 } & Pliocene & \multirow{3}{*}{1000} & & ZYŌ FORMATION & \\
\hline & \multirow[t]{2}{*}{ Miocene } & & & \multicolumn{2}{|c|}{$\begin{array}{l}\text { MIDDLE MIOCENE TO PLIOCENE } \\
\text { VOLCANIC ROCKS }\end{array}$} \\
\hline & & & & \multicolumn{2}{|c|}{ YUGASIMA GROUP } \\
\hline
\end{tabular}

was covered by an open sea where sediments containing mulluscan fossils were deposited (Zyō formation).

The oldest of the Quaternary volcanoes is Usami which was erupted from a centre near the present village of Usami, north of Ito. It is a stratovolcano of pyrcxene andesite (designated as UV in the tables). Some of the lavas which flowed southwestward covered the Zyō formation.

Slightly later the centre of eruption moved about $10 \mathrm{~km}$ northward where another stratovolcano Taga was born. From this centre lavas and pyroclastic materials of pyroxene andesite were erupted in the earlier stage of activity, whereas fluidal lavas of olivine-pyroxene basalt, almost to the exclusion of pyroclastic materials, were extruded in the later stage (all designated as TV).

After a short period of erosion lava domes of dacite were erupted near the centre of Taga and also on its northwestern flank.

Then the centre of activity migrated again about $10 \mathrm{~km}$ north-northwestward, namely to a point near the present town of Yugawara, from which lavas and pyro- 


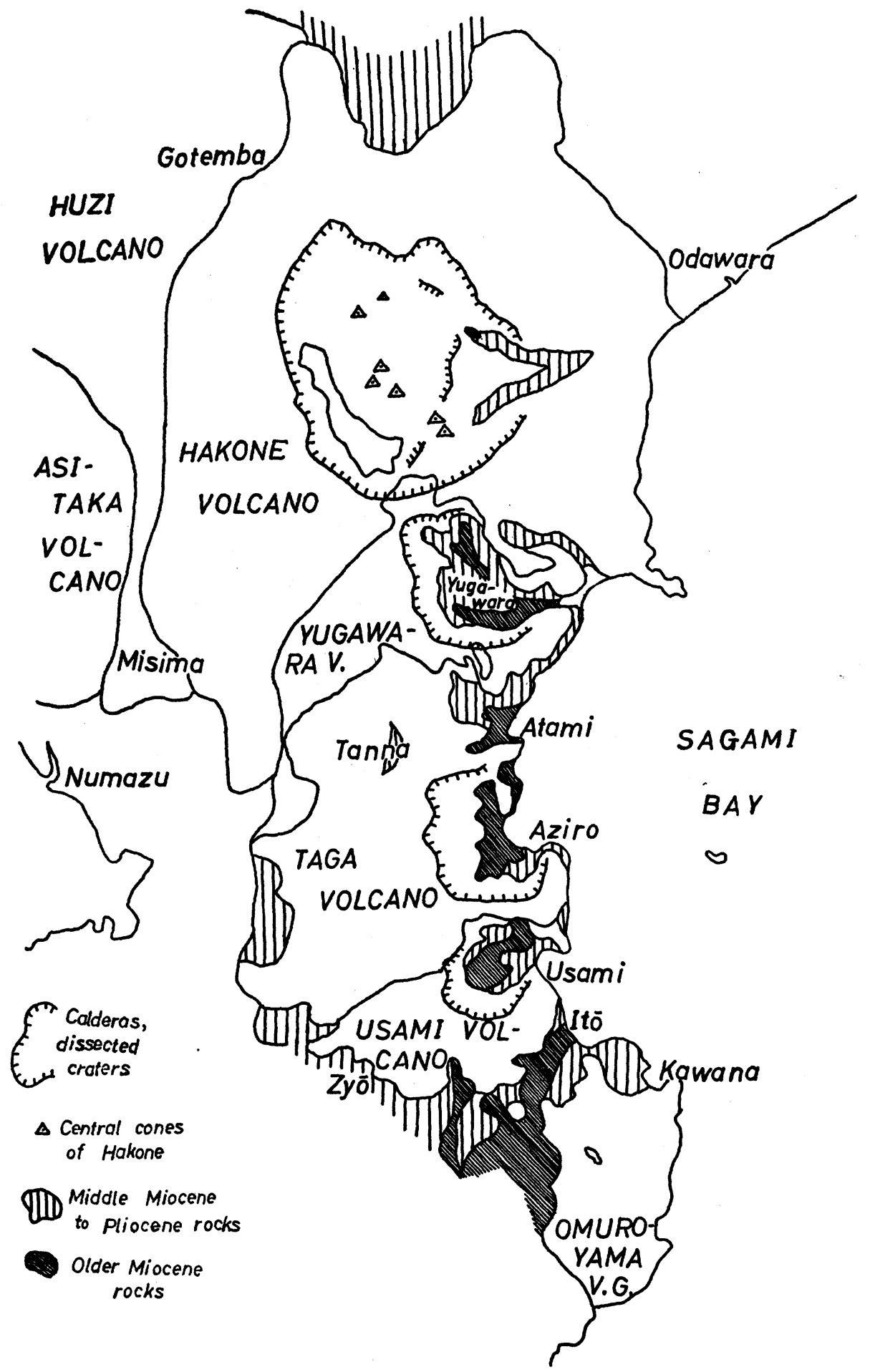

Fig. 2 Map showing the distribution of geologic units in the North-Izu and Hakone volcanic region. 
clastic materials of pyroxene andesite were erupted to form Yugawara Volcano (YV).

Slightly later the activity of Hakone Volcano started from a centre situated about $10 \mathrm{~km}$ north-northwest of the town of Yugawara. The activity of this volcano took place in three distinct stages, the two contiguous stages having been separated from each other by periods of caldera formation and erosion.

During the first stage of activity a stratovolcano about $2700 \mathrm{~m}$ high was built. This eruption was caused at the outset by a magma of olivine-pyroxene basalt and later by that of pyroxene andesite. These rocks are called the Old Somma lavas (OS). Then the top of the cone subsided to form caldera measuring $11 \mathrm{~km}$ in NS diameter and $7 \mathrm{~km}$ in EW diameter. This was followed by a long period of erosion during which more than $800 \mathrm{~m}$ of the Old Somma lavas and the underlying Tertiary rocks in the eastern caldera wall were removed.

The second stage of activity was caused by magmas of salic pyroxene andesite and pyroxene dacite (the Ycung Somma lavas, YS), resulting in a gentle-slored shield volcano within the caldera already formed. At the close of this activity a tremendcus amount of pyroxene dacite magma was drained from the reservoir and produced pumice

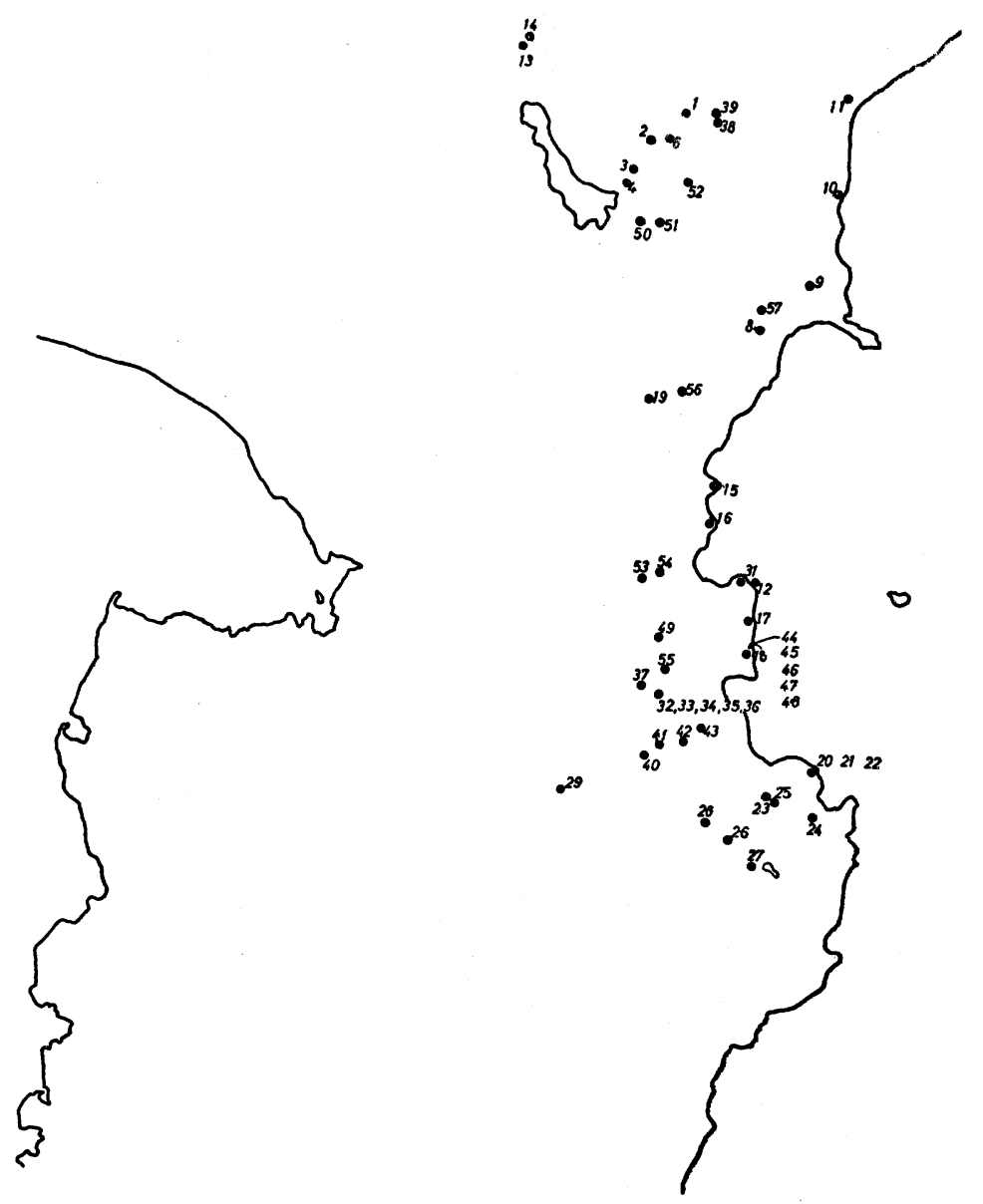

Fig. 3 Localities of outcrops for sampling. 
T. Nagata et al.

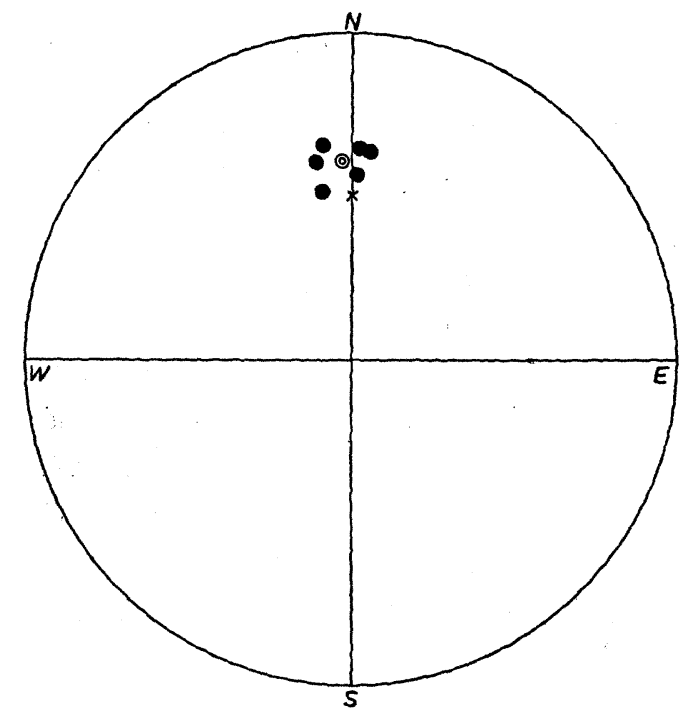

Fig. 4, a

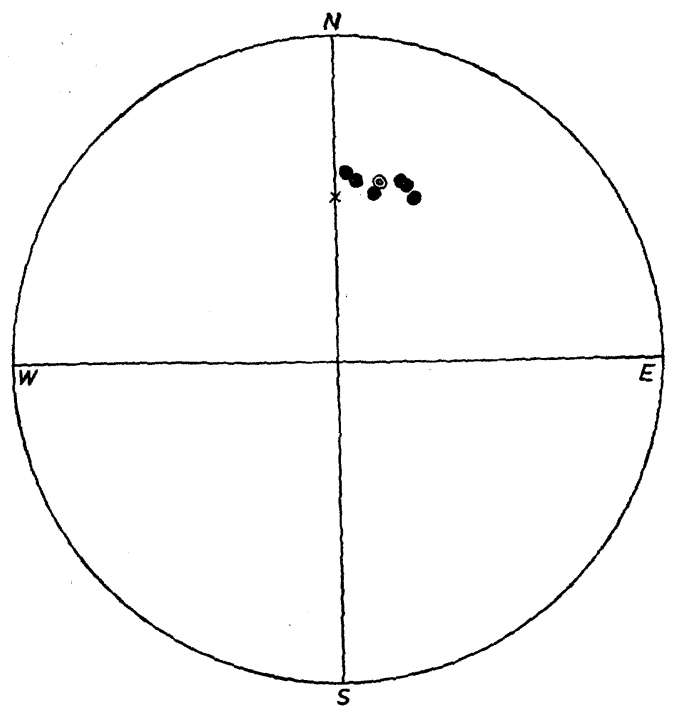

Fig. 4, c -

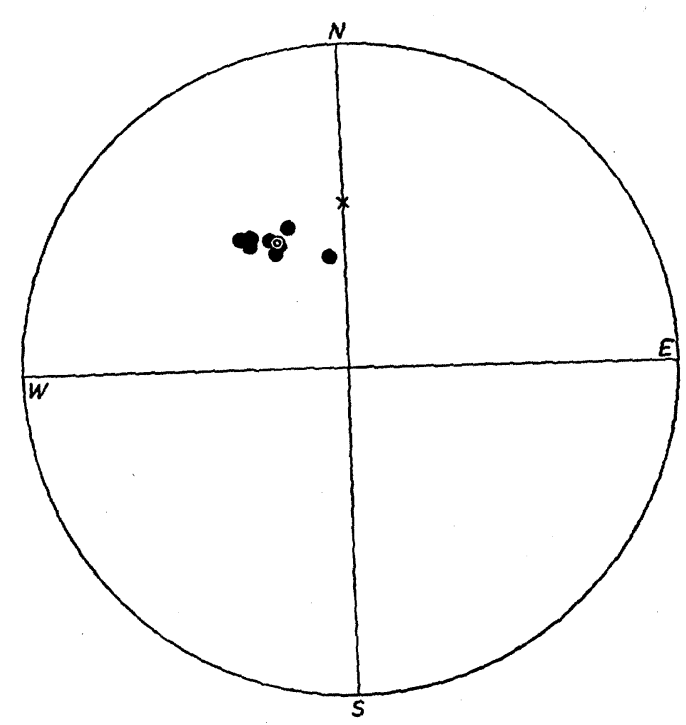

Fig. 4, e

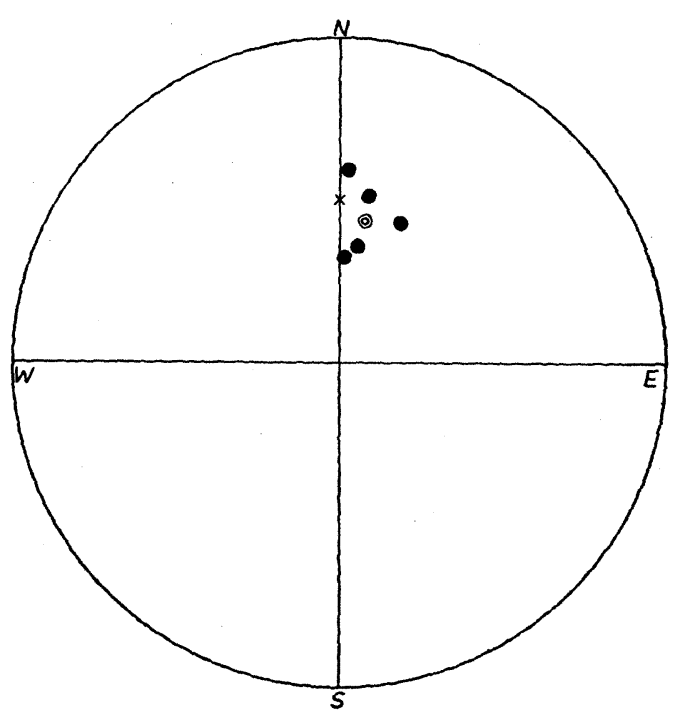

Fig. 4, b

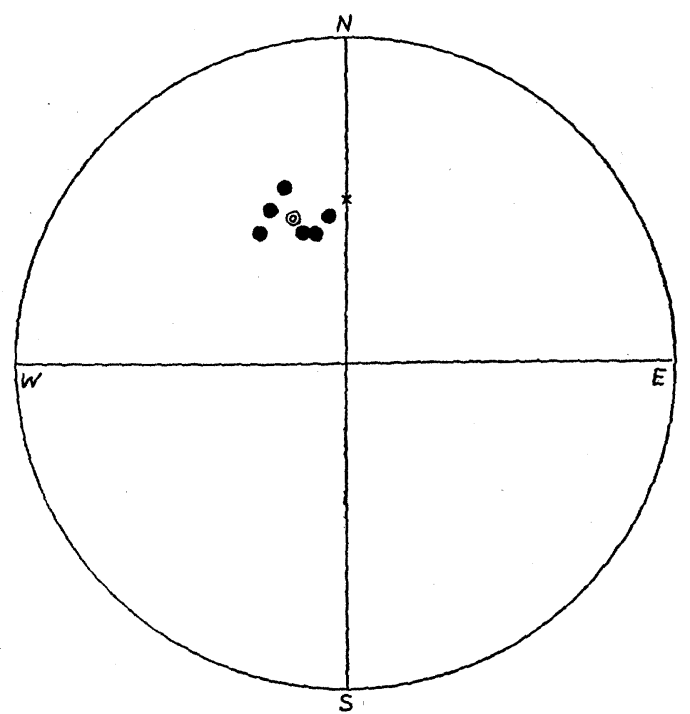

Fig. 4, d

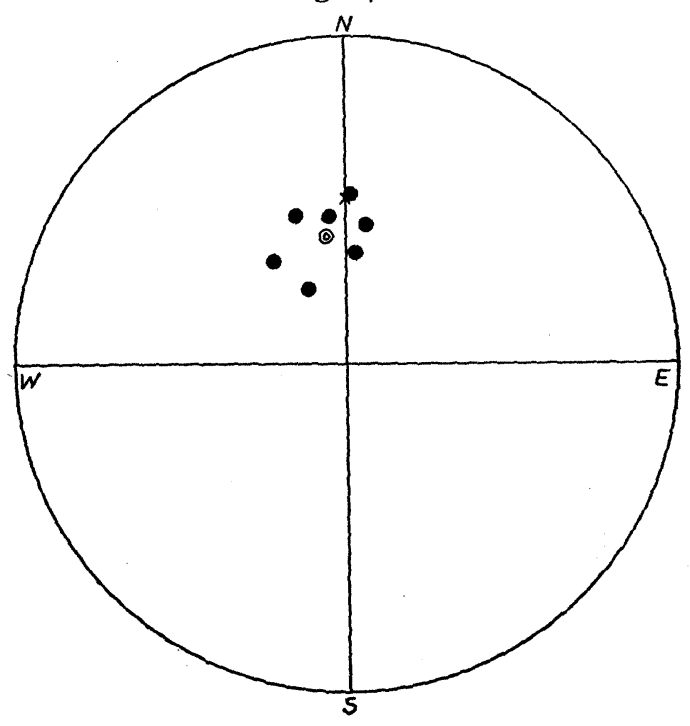

Fig. $4, f$ 


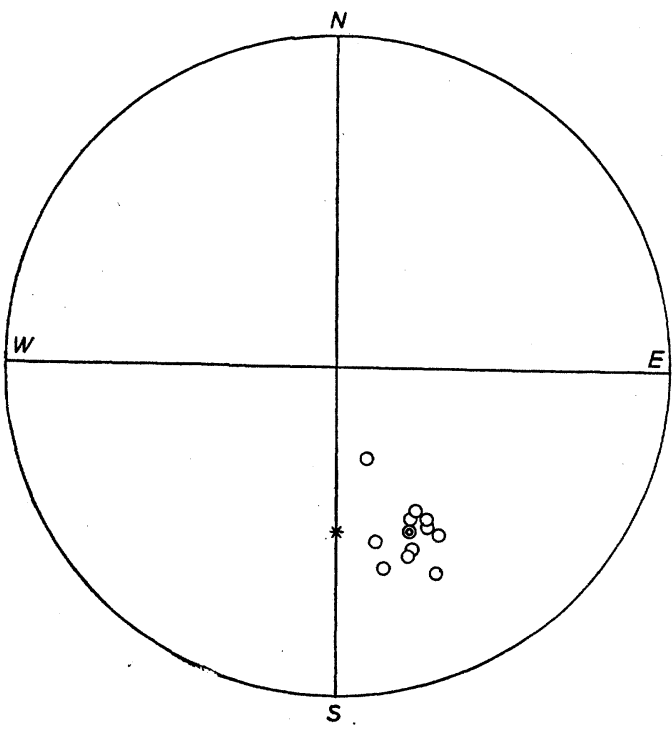

Fig. 4, $g$

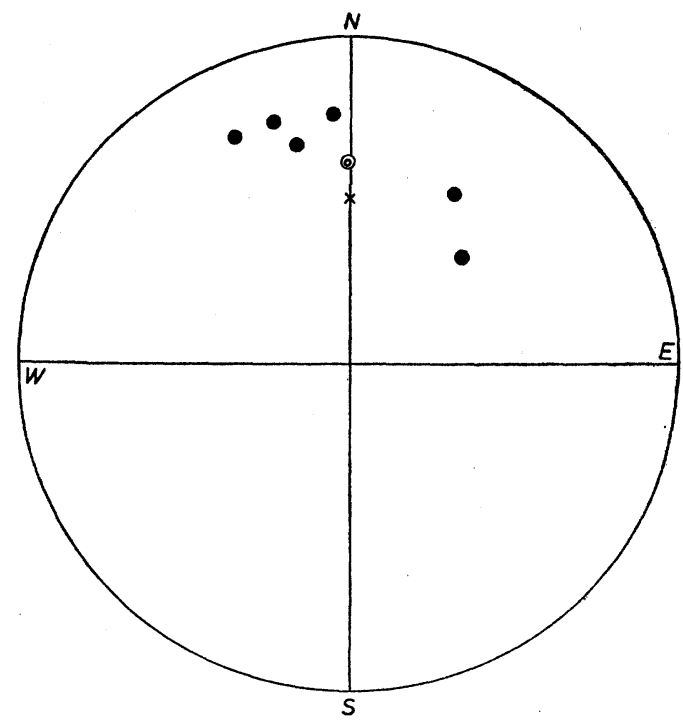

Fig. 4, i

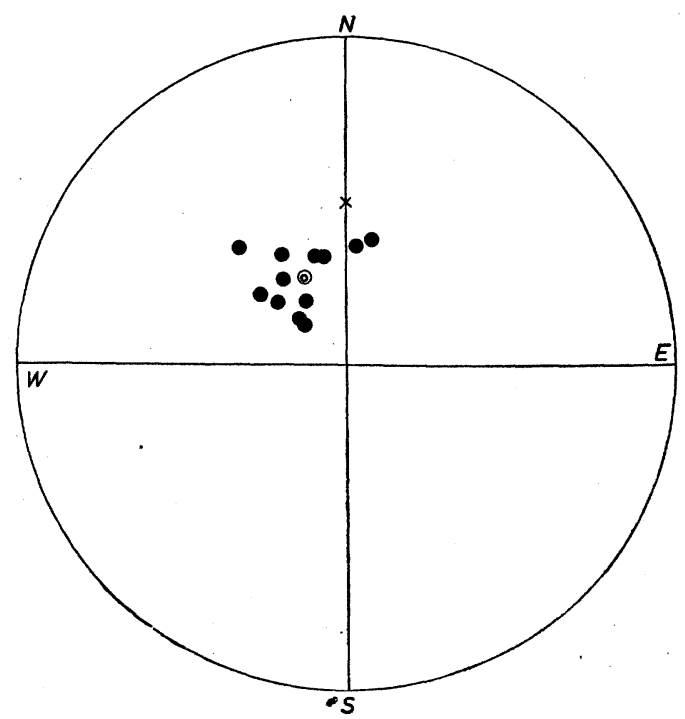

Fig. $4, \mathrm{~h}$

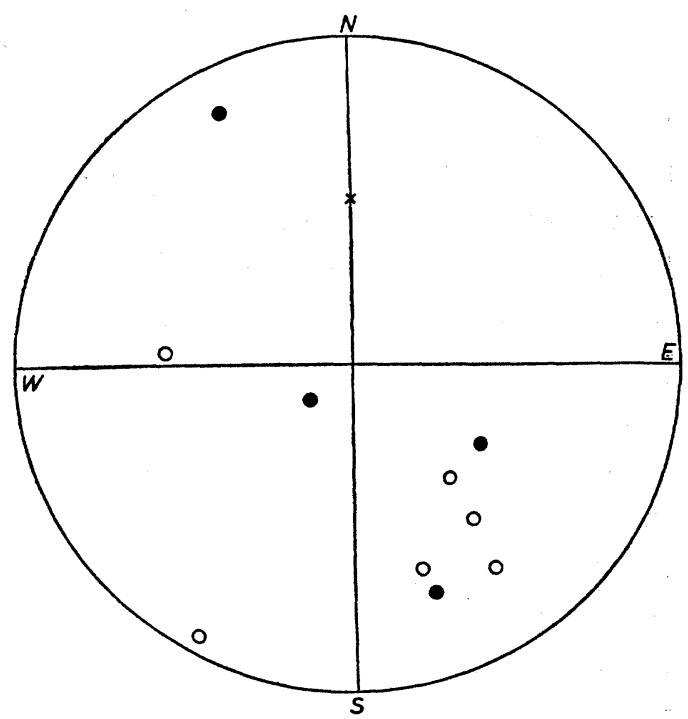

Fig. $4, j$

Fig. 4, a Sample No. 26, andesite of Umenokidaira volcano.

Fig. 4, b Sample No. 9, $\mathrm{O}_{20}$, andesite of Old Somma of Hakone volcano.

Fig. 4, c Sample No. 57, $\mathrm{O}_{12}$, andesite of Old Somma of Hakone volcano.

Fig. 4, d Sample No. 16, $\mathrm{D}_{2}$, pyroxene dacite at Akanezaki.

Fig. 4, e Sample No. 17, $\mathrm{TV}_{5}$, basalt of Taga volcano.

Fig. 4, $\mathrm{f}$ Sample No. 15, $\mathrm{TV}_{1}$, andesite tuff breccia of Taga volcano.

Fig. 4, $g$ Sample Nos.18 and 45, UV, reversely magnetized andesite of Usami volcano.

Fig. 4, h Sample Nos. 20, 21 and 22, UV, normally magnetized andesite of Usami volcano,

Fig. 4, i Sample No. 3, $\mathrm{CC}_{8}$, andesite of a central cone of Hakone volcano: example of poorer uniformity in direction of natural remanent magnetism.

Fig. 4, j Sample Nos. 44 and 46, fragmentary part of andesite of Usami volcano: direction of natural remanent magnetism is widely scattered.

Fig. 4 Examples of direction of natural remanent magnetism in Schmidt projection.

Full circle...... lower hemisphere

Hollow circle .. upper hemisphere 
Double circle .. mean direction

$\times \ldots \ldots \ldots \ldots$....present geomagnetic north

*........... present geomegnetic south

flows. This eruption was succeeded by collapse of the centre of the shield volcano, resulting in a caldera approximating the earlier one in size and location.

After a long period of erosion which gave rise to gorges $300 \mathrm{~m}$ deep cutting through the eastern flank of the shield, the activity of the third stage started. Viscous magma of pyroxene andesite was extruded from vents arranged on or near an NW-SE line passing through the centre of the caldera. Six lava domes and one stratovolcano, which are called the Central Cones (CC), were formed by this activity.

The materials erupted at various stages during the growth of the Hokone Volcano are interbedded with fossiliferous sediments exposed in a region to its northeast. From stratigraphical and palaeontological data obtained from this region, it is infered that the birth of the volcano was probably middle Pleistocene. The materials of the Central Cones is interfingered with younger Pleistocene lapilli and ash from Huzi (Fuji) Volcano lying to the northwest of Hakone. It follows that the activity of Hakone lasted for the later half of the Pleistocene.

To the south of the Usami Volcano, eruption of fluidal basaltic lavas and basaltic scoriae took place during a period from younger Pleistocene to Holocene. These materials built up small lava platforms, shield volcanoes, stratovolcanoes, and pyroclastic cones within a area about $12 \mathrm{~km}$ in maximum diameter. These volcanoes are collectively called the Omuro-yama Volcano Group.

In Table 1 the approximate thickness of the materials composing each unit of Pleistocene is given, together with the period in $10^{3}$ years during which each unit was formed. Each erosion period is roughly estimated in the following ways:

The lavas and pyroclastic materials of Usami, Taga, Yugawara and the Old Somma of Hakone are similar to one another in character. It is assumed therefore that each of these units was accumulated during a period proportional to the thickness of its materials. Thus the earlier half of the Pleistocene (approximately 500,000 years) is divided into three periods according to the thickness of the rocks of Usami, Taga, and Yugawara, separated by short erosion intervals. The period of the Old Somma lava eruption is also estimated according to the thickness of the rocks relative to those of the older units. As the rocks of the Young Somma and Central Cones have quite different lithologic characters from those of the older units, the periods of their eruption may not be proportional to their thicknesses. Each period is estimated as 50,000 years regardless of their thickness. The erosion period between the eruptions of the Old Somma and Young Somma lavas and that between the eruptions of the latter and the Central Cones are roughly estimated as 200,000 and 50,000 years respectively on the basis of the volumes of materials removed.

\section{Results of Measurements on Natural Remanent Magnetism}

Although each unit listed in Table 1 is composed of many layers of lavas and 
pyroclastic materials, some of them are not suitable for the palaeomagnetic study, because they are either made up to fragments that had already been cooled through the Curie point before they came to settle at the present positions (pyroclastic rocks or fragmental parts of some lavas) or subjected to disturbances after the cooling. All samples were therefore collected from solid interior of undisturbed lava flows. One sedimentary rock is also included. These samples were selected so as to represent different horizons within each unit. On each outcrop 4 to 7 oriented samples were collected at points located more than $1 \mathrm{~m}$ apart from one another. The localities of these outcrops are shown in Fig. 3.

The direction and intensity of the natural remanent magnetism were measured for most samples by an astatic magnetometer, whereas those of a few samples with weak remanent magnetism were measured by a spinner type magnetometer.

Some of the results of measurements are illustrated in Fig. 4, a, b, c, d, e, f, g, h, i and $\mathrm{j}$ by the Schmidt projection. They illustrate the degree of concentration of measured directon of the remanent magnetism of individual specimens at a site. Fig. 4, $a, b, c, d, e, f, g$ and $h$ are good examples, Fig. $4, i$ is the example of poorer concentration and Fig 4, j shows how the directons of remanent magnetism are scattered for a group of samples collected from a fragmental part of a lava flow.

Table 2 lists the general results of measurements. The names of the geologic units and rocks refer to those in $\mathrm{H}$. Kuno's paper [4].

The values of direction and intensity of natural remanent magnetism for each site and the error angles for $5 \%$ of direction were calculated from the measurements of 4 to 7 samples by Fisher's method [9]. The layers with cross marks are omitted ones on account of geologcal evidence as, mentioned already. The direction of the geomagnetic centred dipole, listed in the 7th column of the Table 2, were calculated from the measured direction of the remanent magnetism. They are plotted in Fig. 5 in which the full and

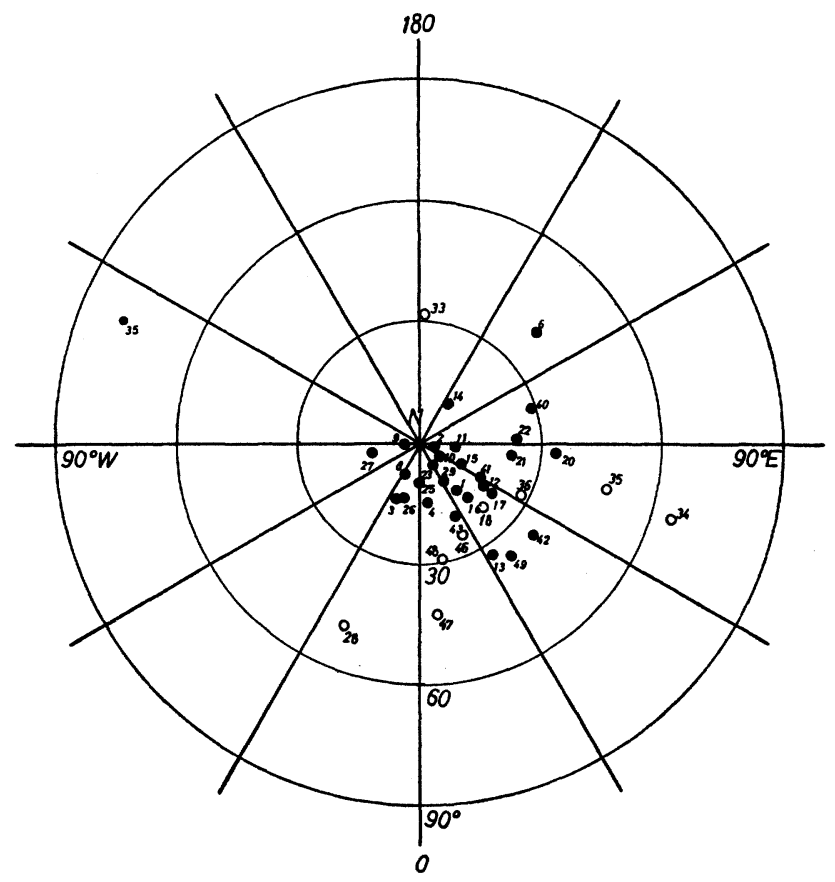

Fig. 5 Directions of geomagnetic centred dipoles deduced from the mean directions of natural remanent magnetism at each outcrops : full circle.... position of north pole hollow circle......... position of south pole centre ............ present geographic pole hollow circles stand for the north and the south poles respectively. It is noted in 
Table 2 and Fig. 5 that the direction of the geomagnetic field has always been the same with that of today during the whole Quaternary age, except for a short period when some of the lavas of the Usami volcano were erupted. During this period of early Quaternary the direction of geomagnetic field was nearly reversed to that of today.

\section{The Reliability Tests}

As we have discussed previously [10], the palaeomagnetic study by means of the natural remanent magnetism of an igneous rock is physically justified when and only when the direction of the natural remanent magnetism is ascertained to have been kept unchanged throughout the time after the rock had been formed. From the present knowledge of rock-magnetism, the above condition may be regarded as satisfied when the natural remanent magnetism in question is proved to be the stable thermo-remanent magnetism of a stable titanomagnetite phase, produced when the rock cooled through the Curie point at the time of formation. Quite recently, the existence of stable chemical remanent magnetization and piezoremanent magnetization has been reported [11] [12]. But, their stability has not thoroughly studied yet and, besides, they are mainly concerned with the remanent magnetization of sedimentary and metamorphic. rocks which we are not dealing with here. We have proposed in the previous paper that a set of practical tests should be applied on the rock specimen, when one wants to use its natural remanent magnetism for palaeomagnetic purpose. The details of the tests being described in that paper [10], we shall only briefly explain them in items here. Since the following criteria are qualitative in nature, some quantitative conditions were tentatively adopted in the present study, as shown in items 1) and 4). Symbols $O, \Delta$ and $\boldsymbol{\Delta}$ mean the "adoptable," "somewhat dubious" and "rejectable" respectively.

Notations to be used are as follows:

$J_{n}(T) \ldots \ldots$ natural remanent magnetism at a temperature $T$.

$J_{T_{c}}(T) \ldots \ldots$ thermo-remanent magnetism at a temperature $T$.

$T_{o} \ldots \ldots$....room temperature.

$T_{c} \ldots \ldots \ldots$ Curie point temperature.

$J_{n}-T \ldots \ldots$ mode of thermal demagnetization of $J_{n}$ by heating up to $T$ and cooling down to $T_{o}$ in non-magnetic space.

$J_{T_{0}}-T \ldots \ldots$ mode of thermal demagnetization of $J T_{c}$ by the same process as in $J_{n}-T$.

$\left(J_{n}\right) \widetilde{H}$....... mode of demagnetization of $J_{n}$ by alternating magnetic field of which maximum intensity is $\widetilde{H}$.

$\left(J_{c}\right) \widetilde{H} \ldots \ldots$ mode of demagnetization of $J T_{c}$ by the same process as in $\left(J_{n}\right) \widetilde{H}$.

$J_{s}(T) \ldots \ldots$ saturation magnetization at a temperature $T$.

\section{The reliability tests}

1) The ratio $J_{n}\left(T_{o}\right) / J_{T_{c}}\left(T_{o}\right)$ should be nearly equal to unity.

$\bigcirc \ldots \ldots .0 .5<J_{n} / J_{T_{c}}<1.5$ 


$$
\Delta \ldots \ldots .0 .2<J_{n} / J_{T_{c}}<0.5 \text { or } 1.5<J_{n} / J_{T_{c}}<2.5
$$

A........ otherwise

2) The modes of $J_{n}-T$ and $J T_{c}-T$ should be similar.

3) The modes of $\left(J_{n}\right) \widetilde{H}$ and $\left(J_{T_{c}}\right) \widetilde{H}$ should be similar.

4) Contained ferromagnetic mineral should exclusively be a single phased titanium-poor titanomagnetite.

$$
\begin{aligned}
& \bigcirc \ldots \ldots \ldots T_{c}>400^{\circ} \mathrm{C} \\
& \triangle \ldots \ldots .400^{\circ} \mathrm{C}>T_{c}>300^{\circ} \mathrm{C} \\
& \Delta \ldots \ldots .300^{\circ} \mathrm{C}>T_{c}
\end{aligned}
$$

5) $J_{s}(T)$ curve measured in vacuum should be reversible with temperature.

The results of these tests are listed in Table 2 by the symbols. As these symbols show, there is no particular indication that the naturally reversely magnetized rocks have any properties which may cause the self-reversal phenomenon. Hence, we find no reason to doubt the reversal of the geomagnetic field at the time when these rocks

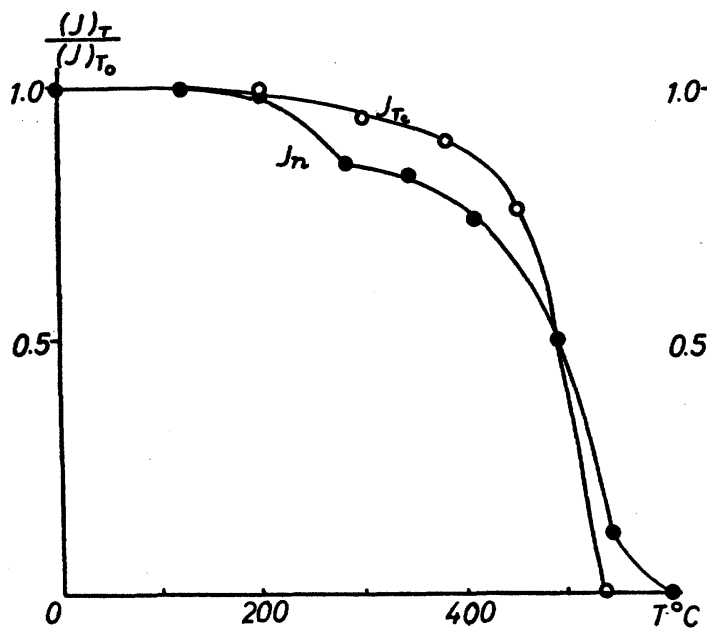

(a)

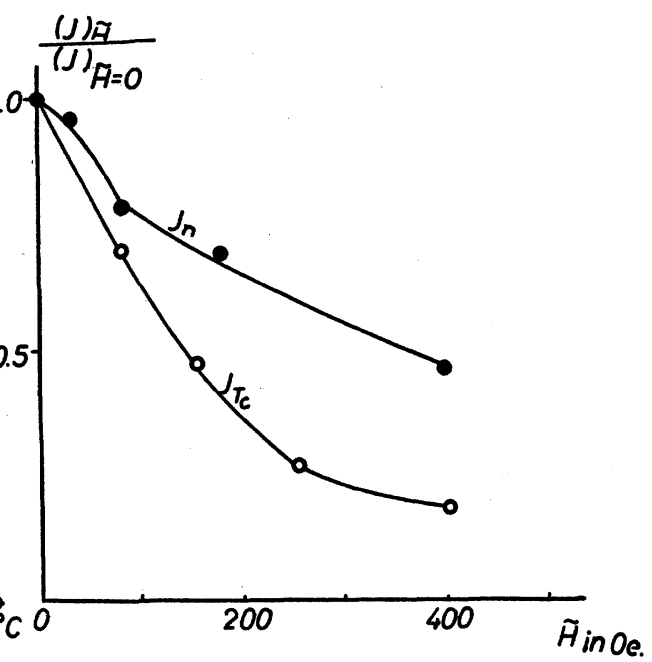

(b)

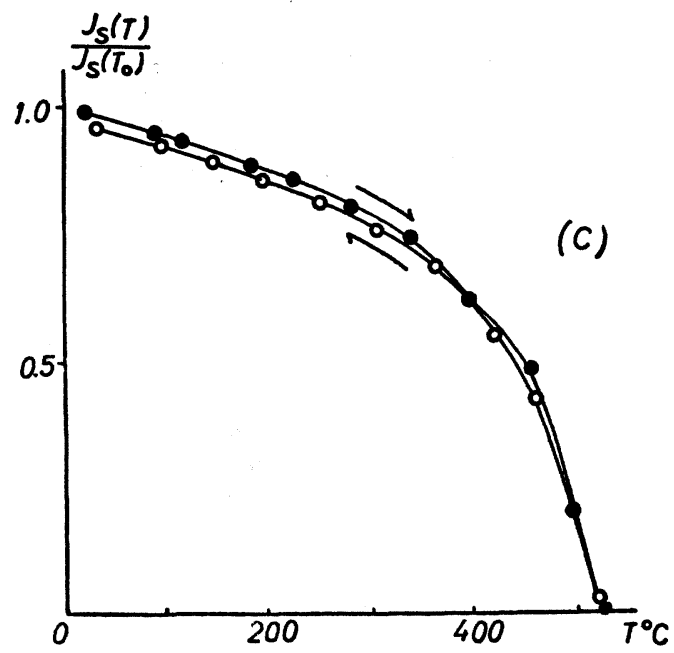

Fig. 6 Reliability tests of natural remanent magnetism : sample: No. $4, \mathrm{CC}_{7}$, andesite $J_{n}$ : normal direction Test 1) $J_{n} / J T_{c}=0.74$

2) see Fig. 6, a

3) see Fig. 6, b

4) see Fig. 6, c

5) $T_{c}=520^{\circ} \mathrm{C}$ 


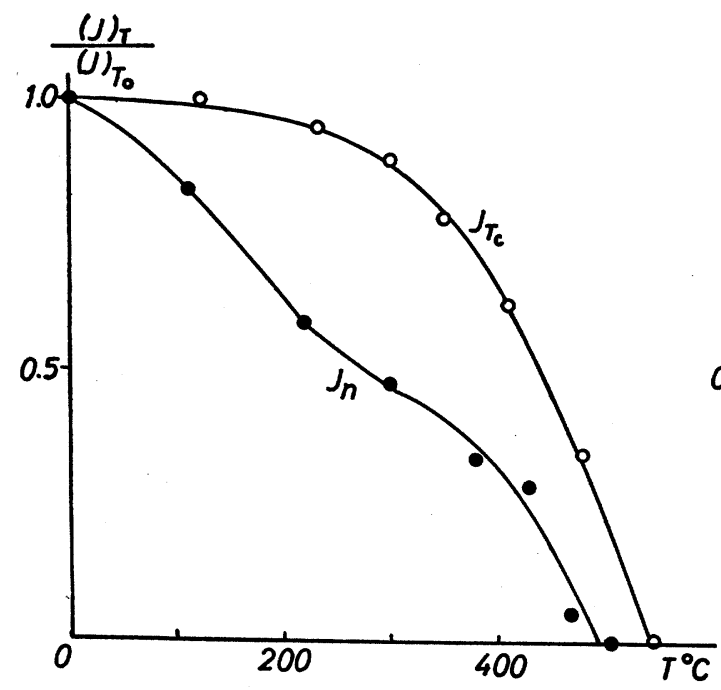

(a)

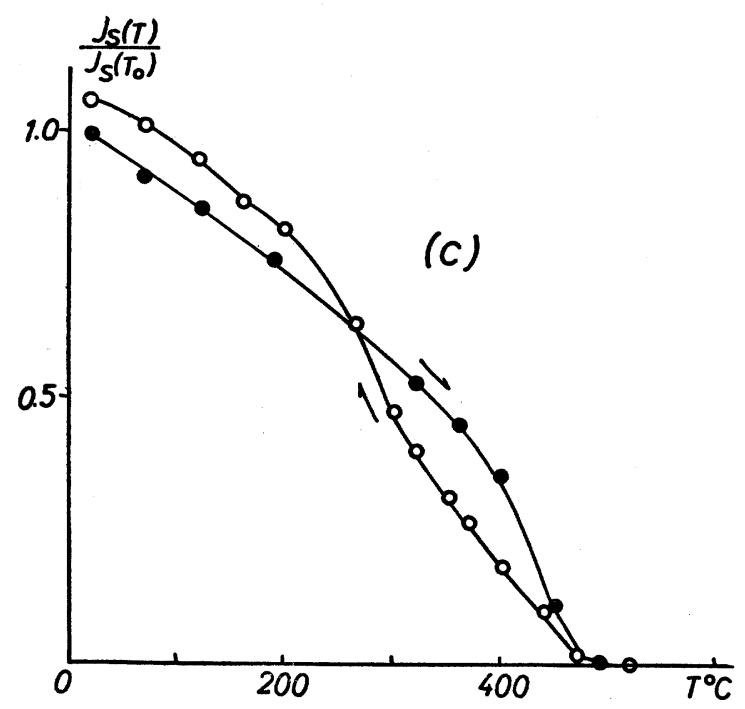

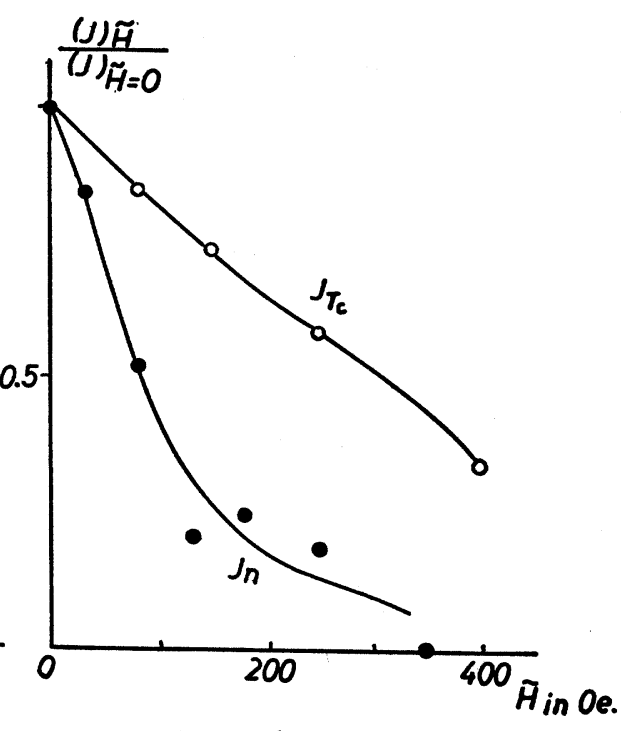

(b)

Fig. 7 Reliability tests of natural remanent magnetism : sample: No. $1, \mathrm{YS}_{3}$, andesite $J_{n}$ : normal direction Test 1) $J_{n} / J T_{c}=0.25$

2) see Fig. 7, a

2) see Fig. 7, b

4) see Fig. 7, c

5) $T_{c}=470^{\circ} \mathrm{C}$ 


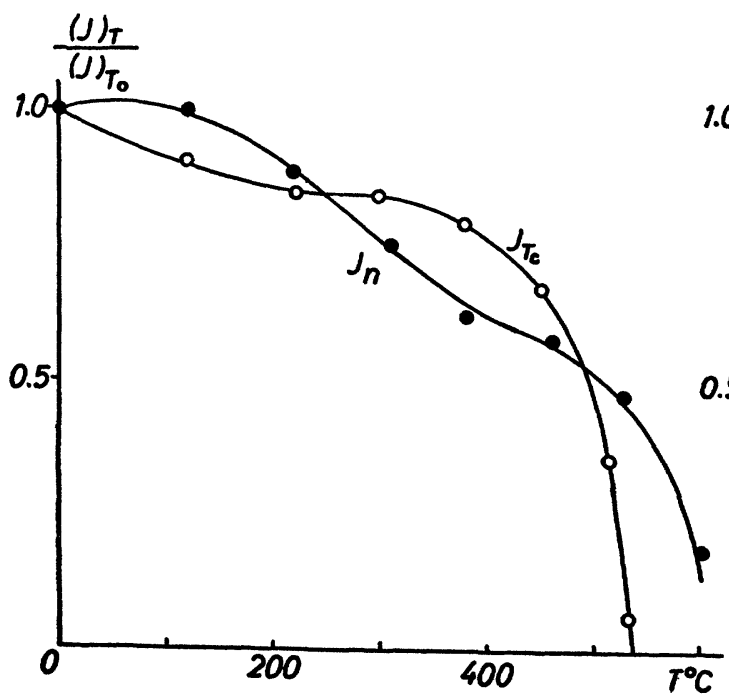

(a)

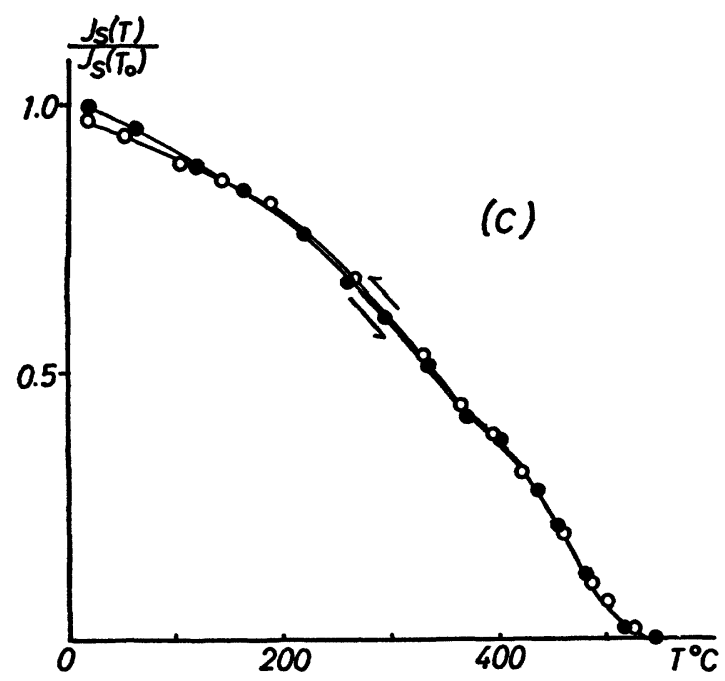

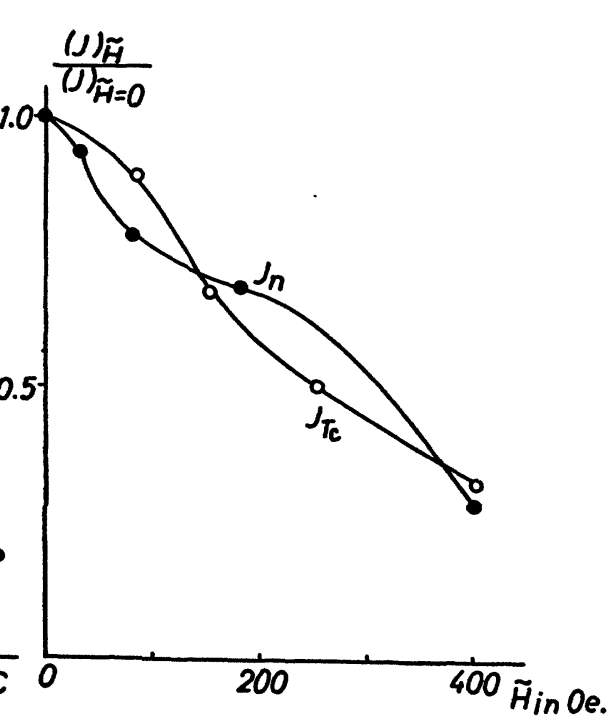

(b)

Fig. 8 Reliability tests of natural remanent magnetism : sample : No. $11, \mathrm{O}_{18}$, andesite Test 1) $J_{n} / / T_{c}=1.32$

2) see Fig. 8 , a

3) see Fig. 8, b

4) see Fig. 8, c

5) $T_{c}=520^{\circ} \mathrm{C}$ 


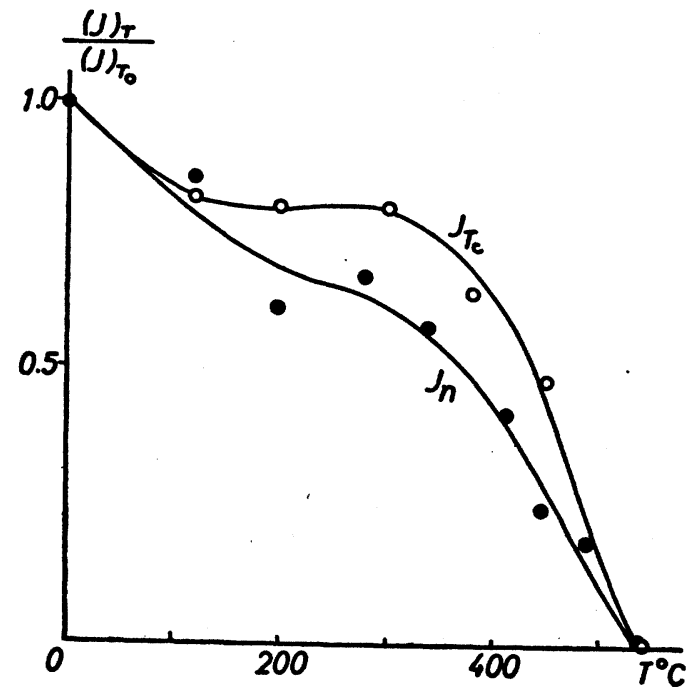

(a)

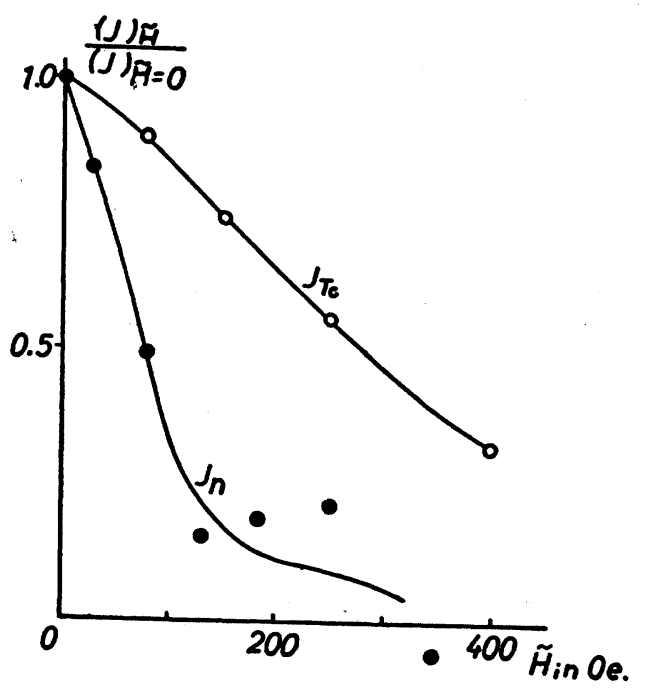

(b)

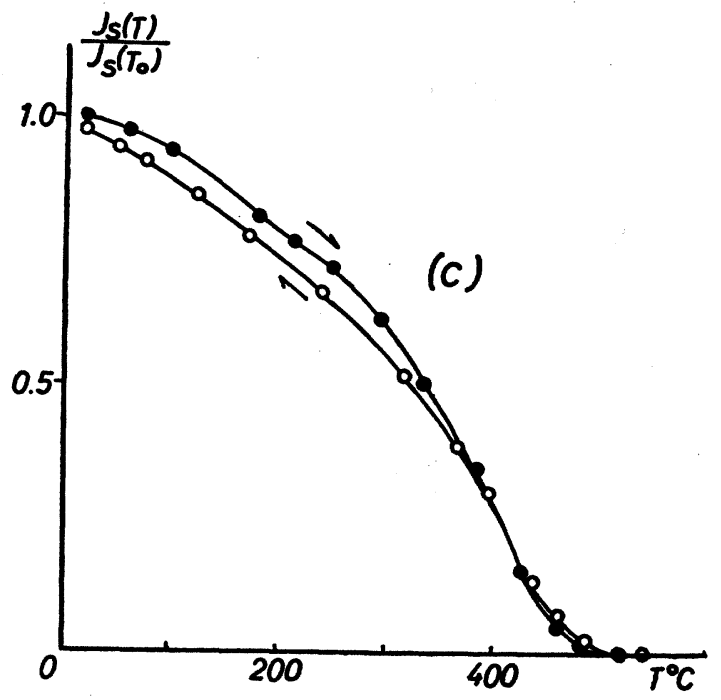

Fig. 9 Reliability tests of natural remanent magnetism : sample : No. 8, $\mathrm{YV}_{1}$, andesite Test 1) $J_{n} / J T_{r}=0.70$

2) see Fig. 9, a

3) see Fig. 9, b

4) see Fig. 9, c

5) $T_{c}=480^{\circ} \mathrm{C}$ 


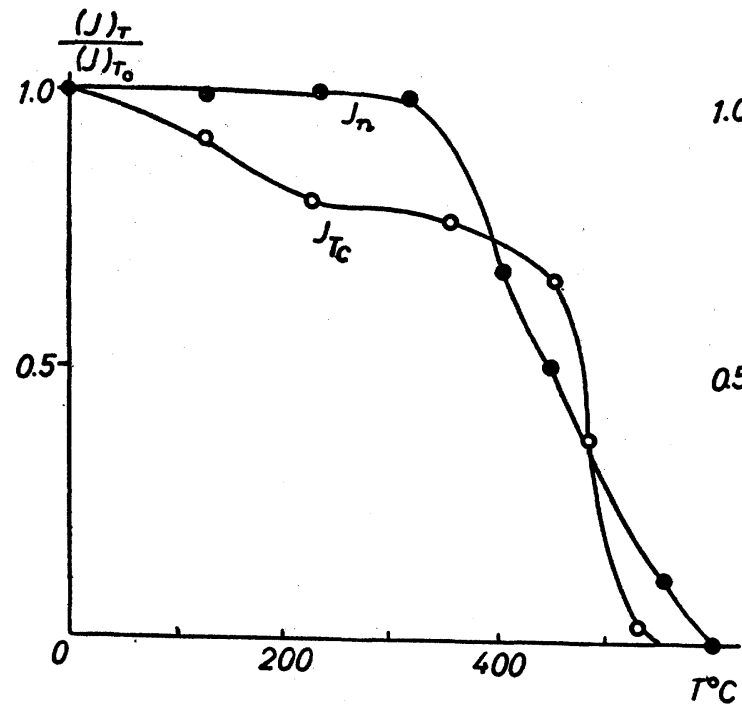

(a)

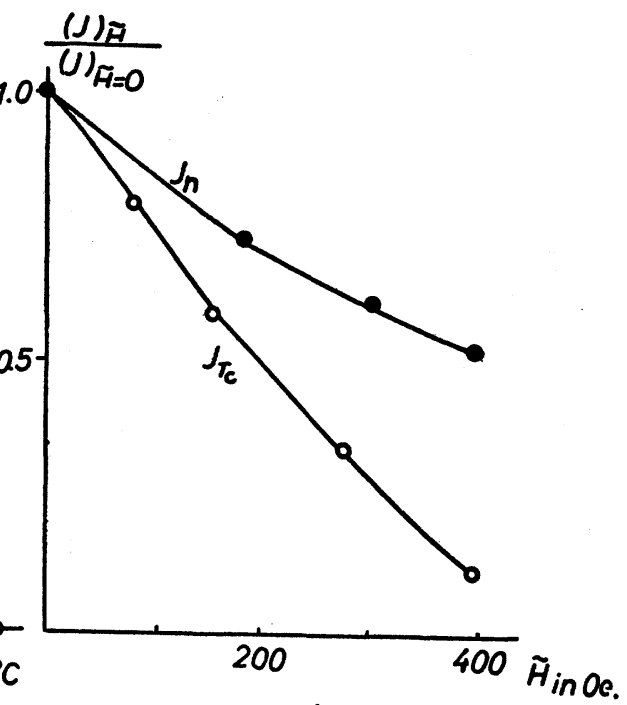

(b)

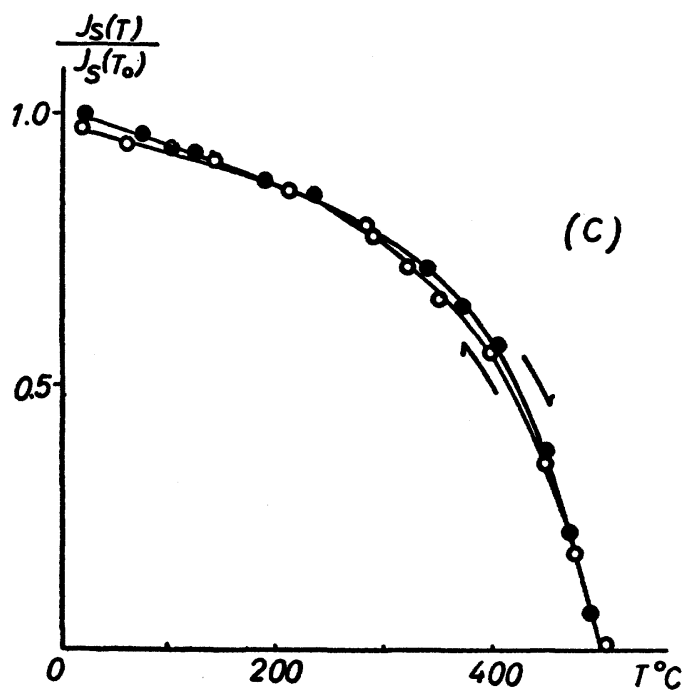

Fig. 10 Reliability test of natural remanent magnetism : sample : No. 18, UV, andesite

$$
\begin{array}{ll}
\text { Test 1) } & J_{n} / J T_{c}=2.4 \\
\text { 2) } & \text { see Fig. } 10, \mathrm{a} \\
\text { 3) } & \text { see Fig. } 10, \mathrm{~b} \\
\text { 4) } & \text { see Fig. } 10, \mathrm{c} \\
\text { 5) } & T_{c}=510^{\circ} \mathrm{C}
\end{array}
$$

were cooled through Curie point. Fig. 6, Fig. 7, Fig. 8, Fig. 9 and Fig. 10 are the examples of the tests performed. Fig. 10 shows the results of the tests for the reversely magnetized rock.

\section{Discussion and Conclusion}

The samples used in the present study cover the period throughout the Quaternary age. Any pair of samples collected from nearest horizons represents a time interval which may not exceed several tens of thousand years except those representing the horizons immediately below and above the long erosion intervals in the history of the 
Hakone Volcano.

Examining the results obtained, it may reasonably be concluded from Fig. 5 that the sense of the direction of the geomagnetic field has remained the same as that of today throughout the Quaternary age, except for a short period during which a few successive lava flows of the Usami Volcano were extruded, and that the pole wandered about the neighbourhood of the present north with periods shorter than the duration of the volcanic activity which produced each unit. In order to show the more general tendency of the polar wandering during the Quaternary age, these rather rapid fluctuations are smoothed out and the value of the geomagnetic field representative of each period of volcanic activity is plotted in Fig. 11. It seems likely, judged from recent geomagnetic secular variation data and results of palaeomagnetic studies on historic and prehistoric baked earth that pseudoperiodic fluctuations of the geomagnetic pole of much shorter period and of less amplitude are superposed on this smoothed curve of general tendency. The absolute time-scale taken for abscissa of Fig. 11 is obtained

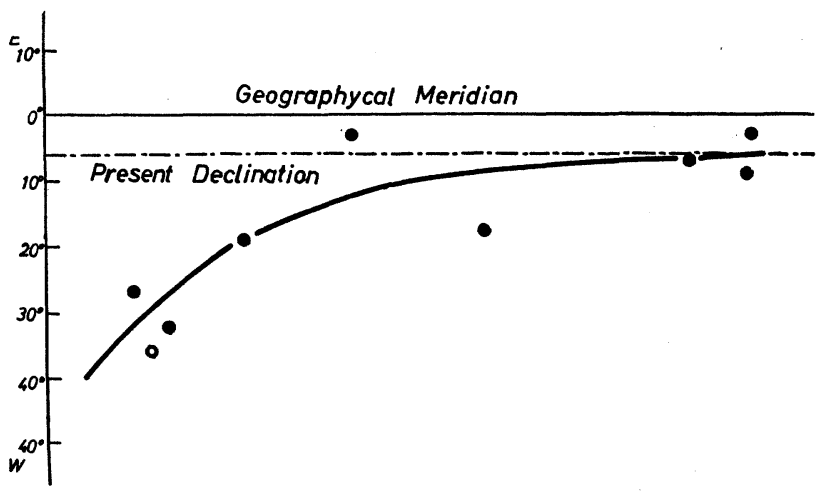
as a mean value of the time range assigned to each unit given in Table 1. The value for the ordinate is the declination measured from the present geographical north and the inclination representative of each period of activity. They are obtained by averaging the values for the localities of the samples belonging to the individual periods of volcanic activity. For the Usami volcano the duration of

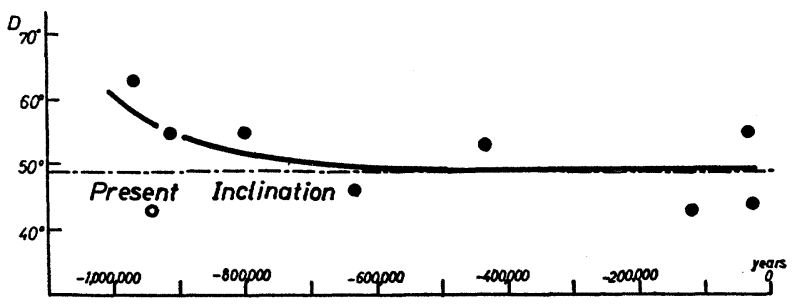
activity was divided into three parts because of the occurrence of reversal of the geomagnetic field. Fig. 12 shows the movement of the geomagnetic north pole calculated from the values in Fig. 11 ; for the reversal time the south pole is plotted by a hollow circle. Viewed from the north, the pole is thus estimated to have shifted clockwise from $72^{\circ} \mathrm{N}, 86^{\circ} \mathrm{E}$ to $81^{\circ} \mathrm{N}, 32^{\circ} \mathrm{W}$. The values shown in Fig. 11 and Fig. 12 are listed in Table 3.

In order to determine the duration through which the reversal lasted, we measured the direction of natural remanent magnetization for many samples of the Usami lavas 


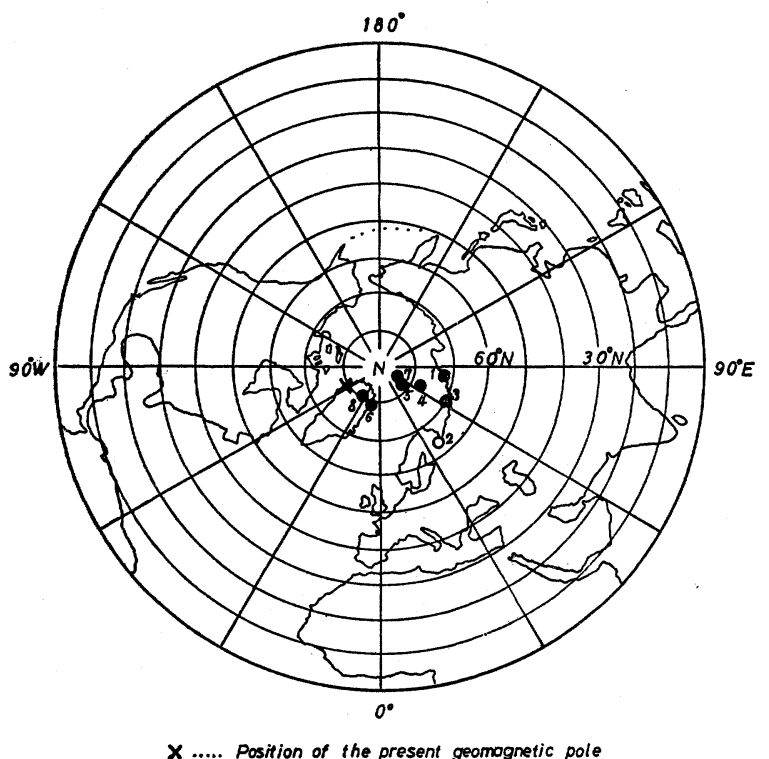

Fig. 12 Position of geomagnetic north (full circle) and south (hollow circle) pole in the Quaternary age as deduced from palaeomagnetic evidence : numbers attached to circles, as in Table 3, represent the geologic units. (see Table 2). It is remarkable that reversal of natural remanent magnetization is found exclusively in the lava flows occurring at the middle horizon of the lava sequence of the volcano. As the duration of the activity of this volcano is estimated as about 100,000 years, the length of the duration of reversal should be a fraction of it.

It has not been possible, so far, to detect the possible change of direction of the transient geomagnetic field, in spite of our numerous meastirements for the layers of lava that had considered to form the boundary between normally and reversely magnetized ones. For example, along the road-cut immediately north of Usami Tunnel,

Table 3.

\begin{tabular}{|c|c|c|c|c|c|c|c|c|}
\hline \multirow{2}{*}{ No. } & \multirow{2}{*}{$\begin{array}{l}\text { Volcanic } \\
\text { activity }\end{array}$} & \multirow{2}{*}{$\mathrm{D}_{0}$} & \multirow{2}{*}{$\mathrm{I}_{0}$} & \multicolumn{3}{|c|}{ error angle for } & \multirow{2}{*}{\multicolumn{2}{|c|}{$\begin{array}{c}\text { Centred dipole } \\
\text { (in geographical } \\
\text { coordinates.) }\end{array}$}} \\
\hline & & & & $\mathrm{p}=0.05$ & $p=0.10$ & $\mathrm{p}=0.50$ & & \\
\hline 8 & OV & $-3^{\circ}$ & $44^{\circ}$ & $14^{\circ}$ & $11^{\circ}$ & $5^{\circ}$ & $81^{\circ} \mathrm{N}$ & $32^{\circ} \mathrm{W}$ \\
\hline 7 & $\mathrm{CC}$ & -9 & 55 & 23 & 19 & 9 & $86 \mathrm{~N}$ & $65 \mathrm{E}$ \\
\hline \multirow[t]{2}{*}{6} & YS & -7 & 43 & 34 & 11 & 8 & $79 \mathrm{~N}$ & $13 \mathrm{~W}$ \\
\hline & Erosion & & & & & & & \\
\hline \multirow[t]{2}{*}{5} & OS & -11 & 53 & 11 & 9 & 5 & $83 \mathrm{~N}$ & $50 \mathrm{E}$ \\
\hline & YV & -3 & 46 & - & - & - & $82 \mathrm{~N}$ & $30 \mathrm{~W}$ \\
\hline 4 & $\mathrm{TV}$ & -19 & 55 & 20 & 17 & 8 & $78 \mathrm{~N}$ & $62 \mathrm{E}$ \\
\hline 3 & $\mathrm{UV}_{3}$ & -33 & 55 & 15 & 13 & 6 & $70 \mathrm{~N}$ & $61 \mathrm{E}$ \\
\hline 2 & $\mathrm{UV}_{2}$ & 146 & -43 & 29 & 23 & 13 & $64 \mathrm{~S}$ & $145 \mathrm{~W}$ \\
\hline 1 & $\mathrm{UV}_{1}$ & -27 & 63 & 12 & 10 & 5 & $72 \mathrm{~N}$ & $86 \mathrm{E}$ \\
\hline
\end{tabular}

northeast of the village of Usami, five successive lava flows are exposed without intervening layers of pyroclastic rocks. Complete absence of weathering products at the top of each flow strongly indicates that they were emplaced in rapid succession. All the flows but the upper-most one show the reverse direction of magnetization. The degree of uniformity of remanent magnetization of the upper-most layer is, as seen in Fig. 13, too poor to be adopted for the palaeomagnetic purpose, especially for such a critical use as a fossil of the geomagnetic field in a transient state from reverse to normal direction. The observed randomness in the direction of natural 
remanent magnetization is regarded as due to the fragmentary nature of the layer.

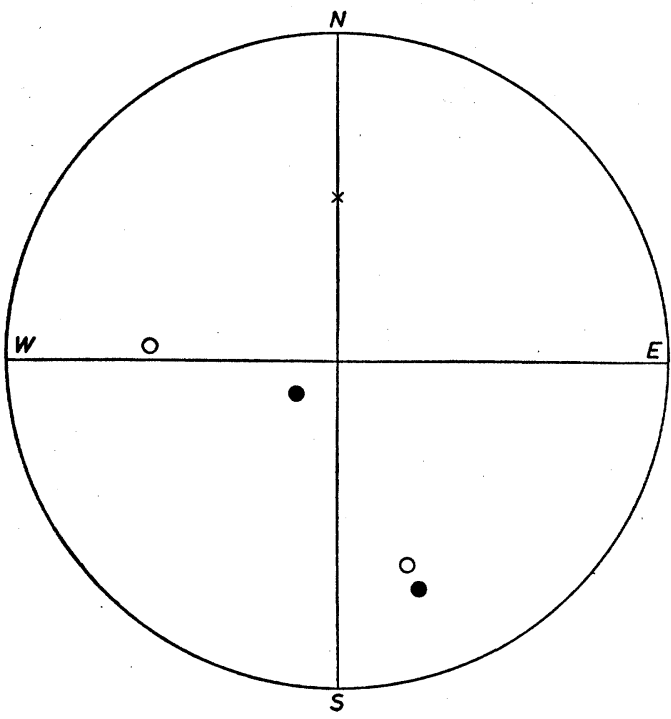

Fig. 13 Direction of natural remanent magnetism of the upper-most layer near Usami Tunnel: sample No. 44, full circle... .lower hemisphere hollow circle....upper hemisphere.

The present theoretical considerations, based on the self-exciting dynamo model of the geomagnetic field, on the other hand, suggest that the reversal of the geomagnetic field would have occurred through vanishing and development of the intensity of the dipole field without accompanied by change in direction, rather than by the migration of the axis of the dipole relative to the axis of the earth's rotation [13]. Our failure in tracing the intermediate directon of the geomagnetic field is, therefore, in agreement with these current views. We could also not find any systematic variation in the intensity of remanent magnetization of normally and reversely magnetized rocks. It may be concluded, from the result obtained so far, that the change

from the normality to reversal or vice versa took place fairly suddenly in comparison with the rate of accumulation of lava flows. More detailed investigations on the remanent magnetization of rocks emplaced at the reverse-normal boundary are now in progress. Evidence of sudden reversal of remanent magnetization has recently been reported by $\mathrm{M}$. Almond, J. Clegg and J. C. Jaeger for Tasmanian Tuff of Triassic age [14].

Finally, it is of much interest to compare our data with those obtained in Iceland by J. Hospers [5] and T. Einarsson and Th. Sigurgeirsson [6], and in France by A. Roche [7]. Both data seem to be in good agreement with ours in that the last occurrence of the reversal of the geomagnetic field was in the early Quaternary age. But, as for the duration of the reversal, our data obtained so far seem to suggest that it was shorter than that suggested by the data in Iceland.

\section{References}

[1] S. K. Runcorn, Adv. in Phys., suppl. Phil. Mag., 4, No. 14, 244 (1955).

[2] P. M. S. Blackett, Lectures on Rock Magnetism, Jersalem 1956.

[3] E. Irving, Geofisica pura e appl., 33, 23 (1956).

[4] H. Kuno, Journ. Fac. Sci., Univ. Tokyo, sec. 2, 7, 257 (1950).

Journ. Fac. Sci., Univ. Tokyo, sec. 2, 9, 241 (1952).

[5] J. Hospers, Koninkl. Nederel. Akad. van Wetenschappen Amsterdam, B 56, 467, 477 (1953). J. Geol., 63, 59 (1955).

[6] T. Einarsson and Th. Sigurgeirsson, Nature, 175, 892, (1955). 


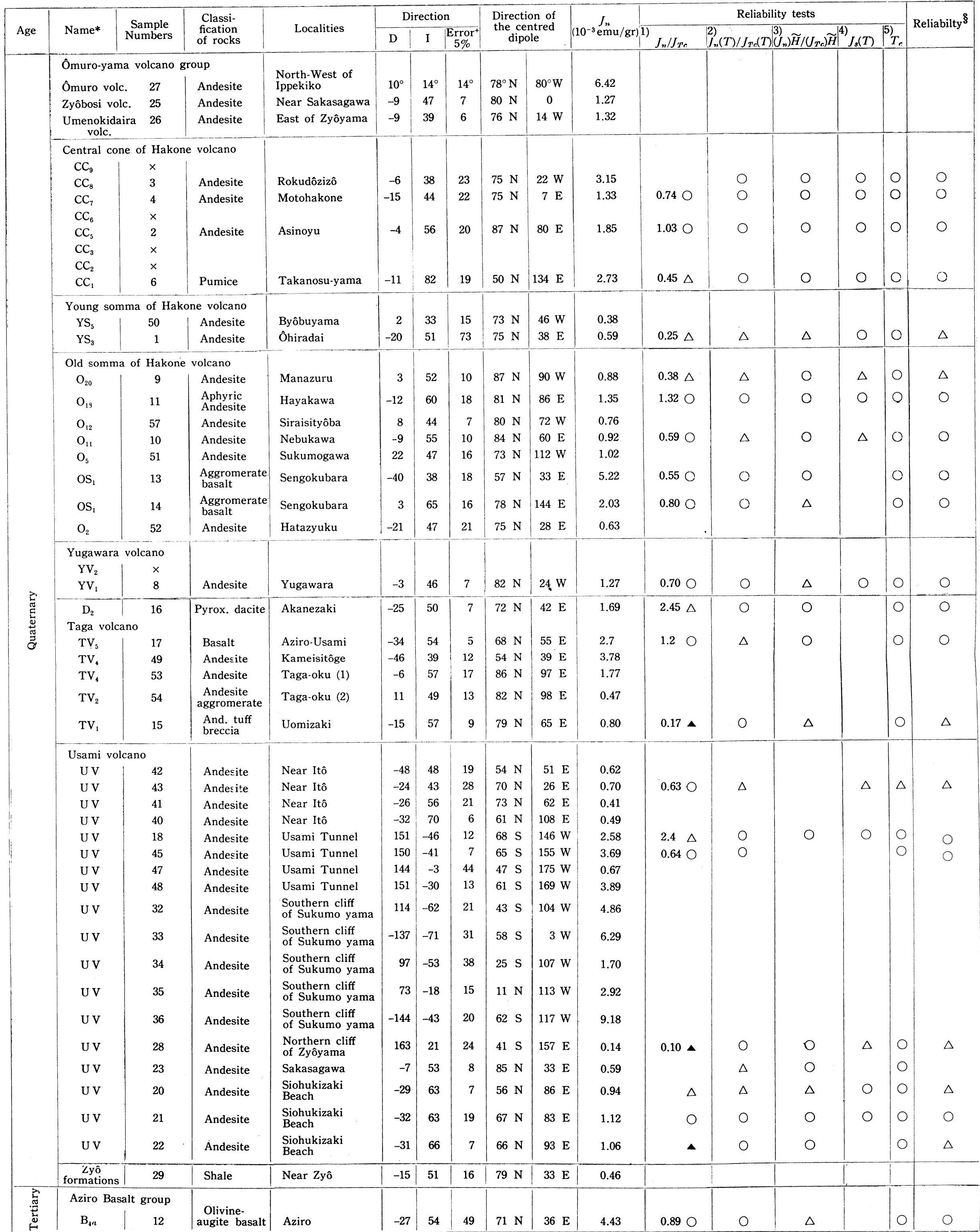

* The symbols refer to those used by H. Kuno in his geologic maps attached to the paper cited.

+ The error angles for 5\% are calculated by Fisher's method.

$\S$ Reliability for paiacomagnetic purpose. 
[7] A. Roche, C. R. Acad. Sci., 233, 1132 (1951). C. R. Acad. Sci. Paris, 243, 812 (1956).

[8] Y. Kato, Hattori Hôkôkai Kenkyu Hôkôku, 9, 282 (1941).

[9] R. A. Fisher, Proc. Roy. Soc., A, 27, 295 (1953).

[10] T. Nagata, S. Akimoto, S. Uyeda, K. Momose and E. Asami, Journ. Geomag. Geoelec., 6, 182 (1954).

[11] R. Doell, Trans. Amer. Geophys. Union, 37, 156 (1956).

[12] N. Kawai and H. Domen, Private Communication.

[13] W. M. Elsasser, Reviews of Modern Physics, 28, 135 (1956)

[14] M. Almond, J. A. Clegg and J. C. Jaeger, Phil. Mag., Aug. 1956, 1 (1956). 